\title{
Risk Factors for Brain Metastases in Patients with Non-Small Cell Lung Cancer: A Meta-Analysis of 43 Studies
}

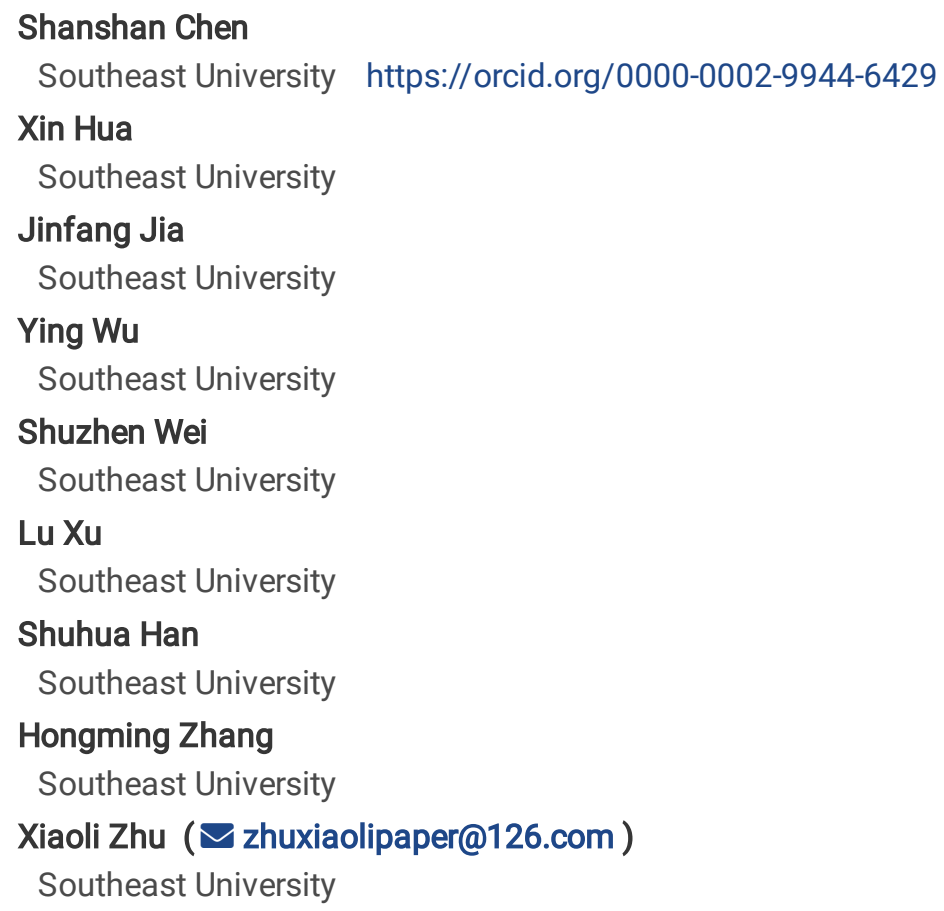

Research

Keywords: Non-small cell lung cancer, brain metastases, risk factors, meta-analysis, prognosis

Posted Date: August 19th, 2020

DOl: https://doi.org/10.21203/rs.3.rs-52317/v1

License: @) (7) This work is licensed under a Creative Commons Attribution 4.0 International License. Read Full License

Version of Record: A version of this preprint was published at Annals of Palliative Medicine on April 1st, 2021. See the published version at https://doi.org/10.21037/apm-20-1722. 


\section{Abstract}

Background: Lung cancer is a leading cause of cancer-related mortality worldwide. The purpose of our meta-analysis was to assess the risk factors for brain metastases in patients with non-small cell lung cancer.

Methods: Multiple databases, including PubMed, EMBASE, Cochrane Library, CNKI and Wanfang were systematically searched, then the meta-analysis was performed with RevMan 5.3 software and carried out evidence quality evaluation according to the GRADE standard. The estimated odds ratio and $95 \%$ confidence intervals were set as effect measures. Moreover, funnel plots and sensitivity analysis were used to assess the publication bias and reliability of the articles, respectively.

Results: A total of 43 studies with 11415 participants were eligible. The results indicated that female, adenocarcinoma or nonsquamous cell carcinoma, advanced tumor stage, node stage, 1ymphatic metastasis, epidermal growth factor receptor gene mutation, kirsten rat sarcoma viral oncogene gene mutation, and higher levels of carcinoembryonic antigen, carbohydrate antigen 199, cytokeratin-19 fragment, neuron-specific enolase and carbohydrate antigen 125 were significantly associated with an increased risk of brain metastases $(P<0.05)$ in non-small cell lung cancer patients. Moreover, the non-small cell lung cancer with brain metastases group had a significantly lower survival rate than the non-small cell lung cancer group $(P<0.05)$.

Conclusions: The meta-analysis demonstrated that non-small cell lung cancer patients with brain metastases have more aggressive clinical features and poor survival prognosis.

\section{Introduction}

Lung cancer is one of the most common malignant tumors worldwide. ${ }^{1}$ Among lung cancer patients, non-small cell cancer (NSCLC) is the most common histology, approximately $80 \% \sim 85 \%{ }^{2}$ The diagnosis of NSCLC usually based on tumor markers, imaging and histopathological characteristics considering the early clinical symptoms of NSCLC are not typical. According to the statistics, around $40 \%$ of NSCLC patients have already combined with metastatic diseases when they are diagnosed, ${ }^{3,4}$ with the most common location for metastasis including the brain, bone and liver et al. Despite an increasing number of progress in therapy, ${ }^{1}$ the prognosis for patients with advanced lung cancer is still mean, especially for patients combined with brain metastases (BM). ${ }^{5}$

According to the previous studies, BM is an important reason for morbidity and mortality for cancers, approximately $20 \%-40 \%$ of NSCLC patients will develop BM, ${ }^{6}$ and the median survival period of NSCLC patients with BM is only about $3 \sim 6$ months. ${ }^{7}$ Although some targeted methods can play a role in controlling intracranial metastases tumor, there are little drugs can cross the blood-brain barrier effectively. ${ }^{8}$ Radiation therapy and surgical operation are the most effective treatment for BM now, but these two treatments may influence patients' quality of life obviously. ${ }^{9}$ Therefore, a greater assessment of the risk factors of NSCLC patients associated with BM becomes a rising concern, which can not only offer an earlier prevention and treatment of BM but also help patients achieve a prolonged survival. A pooled analysis of the association between BM and NSCLC has not been performed. The purpose of our meta-analysis was to summarize the risk factors, clinical characteristics and survival rates of NSCLC patients with BM.

\section{Materials And Methods}

\section{Search strategy}

Different databases, including PubMed, EMBASE, Cochrane Library, CNKI and WanFang were systematically searched for studies without language, publication and time restrictions (from incipiency to December 2019). The search terms included "brain metastases", "nervous metastases" or "cerebral metastases" and "non-small cell cancer", "lung cancer" or "lung malignant disease". Finally, we sifted the references of the relevant studies to identify potentially related articles.

\section{Eligibility/Exclusion criteria}

\section{Inclusion criteria}

i. Studies assessing the clinical features and prognosis of the NSCLC patients with BM. 
ii. The diagnostic criteria of NSCLC and BM were clear and unified, including histologically or cytologically confirmed NSCLC; imaging findings including computed tomography (CT), magnetic resonance imaging (MRI) or positron emission tomography (PET) confirmed BM.

iii. At least one of the outcome measures of interest was provided in the study or could be calculated from the published data.

iv. The number of cancers in the article was more than 20.

\section{Exclusion criteria}

i. Studies based on overlapping patients.

ii. Meta-analyses, reviews, case reports or reports based on expert experience.

iii. No effective data could be extracted.

\section{Data extraction and assessment of study quality}

Two reviewers (Chen and Hua) independently extracted the data from all included studies, and any disagreements were resolved by discussion. The following data were retrieved from the studies: (i) basic characteristics of the included studies, including the first author's name, year of publication, country, and characteristics of the study population (gender, age, number), and study design. (ii) multivariable ORs of clinical characteristics, including age, gender, smoking history, treatment history, pathological type, Tumor ( $T$ ) stage, Node (N) stage, 1ymphatic metastasis, distant metastasis (except outside the brain), epidermal growth factor receptor (EGFR) gene mutation, kirsten rat sarcoma viral oncogene (KRAS) gene mutation and ECOG scale. (iii) clinical laboratory parameters, including the levels of carcinoembryonic antigen (CEA), carbohydrate antigen 199 (CA199), cytokeratin-19 fragment (CYFRA21-1), neuron-specific enolase (NSE) and carbohydrate antigen 125 (CA125).

The quality of the included studies was assessed with the Newcastle-Ottawa Scale (NOS) ${ }^{10}$ and scores of 5-9 were considered fair, while scores of 1-4 indicated a high risk of bias. Cochrane Risk of Bias Tool was also used by two independent viewers, and following criteria were used to evaluate bias in each trial: random sequence generation; concealment of allocation; blinding of participants and personnel; blinding of outcome assessment; incomplete data; The risk of bias was classified as "unclear", "low" or "high".

\section{Evaluation of evidence quality}

The results of meta-analysis were evaluated using the GRADE profiler, and degradation were considered in terms of evidence quality including risk of bias, inconsistency, indirectness, imprecision and publication bias, while upgradation were decided by large effect, plausible confounding and dose-response gradie. ${ }^{11}$

\section{Statistical analysis}

We utilized the RevMan 5.3 software to analyze the data in our meta-analysis. The estimated odds ratio (OR) and weighted mean difference (WMD) was used to evaluate the affiliation between the event of BM and the clinicopathologic features of NSCLC patients. All statistic values were reported with $95 \%$ confidence intervals $(95 \% \mathrm{Cls})$, and the two-sided $P$ value threshold for statistical significance was set at 0.05 . The Chi-square test and the $R$ statistic were used to evaluate heterogeneity among studies. In expansion, $I^{2}$ more than $50 \%$ and $P<0.05$ for the Chi-square test suggested significant heterogeneity among the included studies. When the hypothesis of homogeneity was not rejected, a fixed-effects model was used. Otherwise, a random-effects model was used to estimate OR and $95 \% \mathrm{Cls} .{ }^{12}$ To investigate the effects of individual studies on the overall results, we also performed a sensitivity analysis by excluding each study in turn. In the end, potential publication bias was tested by a funnel plot. Because the number of included studies too small may inevitably result in publication bias, funnel plots were generated for indexes with more than 10 relevant studies. ${ }^{13}$

\section{Results}

\section{Baseline study characteristics and quality assessment}


We identified 14289 studies in our efficient literature search as shown in Fig. 1, and 36 studies were excluded because they were reduplicative studies. After checking the title and abstract, we retrieved 138 potential studies to review the full-text manuscript. At that point, 95 studies were avoided because they lacked an outcome of interest or since they had no compelling information and control groups. Ultimately, 43 studies met our selection criteria for the final analysis. The characteristics and demographic data of all studies included are presented in Table 1. ${ }^{14-56}$ The retrieved studies were published from 2004 to 2019, and a total of 11415 patients were recruited. Of all studies, 26 were cohort studies and other 17 were case-control studies.

For quality assessment, the NOS was used for evaluation because all of the included studies were case-control studies or cohort studies. The results showed that all included studies were of fair quality (Table 1).

\section{Meta-analysis of clinical characteristics of patients}

A meta-analysis of the relevant studies suggested that the prevalence of BM was significantly higher among female patients $(\mathrm{OR}=1.18,95 \% \mathrm{Cl}: 1.11-1.25, P<0.00001)$ (Fig. 2B). Nevertheless, patients with younger than 60 years old $(\mathrm{OR}=1.11,95 \% \mathrm{Cl}: 0.78-1.59$, $P=0.55)$ (Fig. 2A), a smoking history ( $\mathrm{OR}=1.06,95 \% \mathrm{Cl}$ : 0.78-1.46, $P=0.070)$ (Fig. $2 \mathrm{C}$ ) and a treatment history (OR=0.84, 95\% Cl: $0.62-$ 1.14, $P=0.27$ ) (Fig. 2D) did not show significant differences between BM with NSCLC group and sample NSCLC group. Obvious heterogeneity was observed among age $(I=99 \%, P<0.00001)$ and a smoking history $\left(I^{2}=69 \%, P<0.00001\right)$, thus a random-effects model was utilized. In addition, a fixed-effects model was used for the other indexes as there was no obvious heterogeneity of the above studies.

\section{Meta-analysis of tumor-related indexes}

A meta-analysis of the relevant studies suggested that NSCLC patients with adenocarcinoma (OR=2.43, 95\% Cl: 1.92-3.08, $P<0.00001)$ (Fig. 3A) was a risk factor for BM. Conversely, squamous carcinoma was a protective factor ( $\mathrm{OR}=0.39,95 \% \mathrm{Cl}: 0.27-0.54, P<0.00001$ ) (Fig. 3B). Meanwhile, the prevalence of $\mathrm{BM}$ was significantly higher among patients with higher $\mathrm{T}$ stage $(\mathrm{OR}=1.37,95 \% \mathrm{Cl}: 1.04-1.82$, $P=0.03$ ) (Fig. 3C), higher N stage ( $\mathrm{OR}=2.01,95 \% \mathrm{Cl}$ : 1.25-3.22, $P=0.004)$ (Fig. 3D), with the number of 1ymphatic metastasis larger than $6(\mathrm{OR}=2.86,95 \% \mathrm{Cl}: 1.89-4.33, P<0.00001)$ (Fig. 3E), EGFR gene mutation (OR=2.45, 95\% Cl: 1.65-3.65, $P<0.00001)(\mathrm{Fig} .3 \mathrm{G})$ and KRAS gene mutation ( $\mathrm{OR}=2.88,95 \% \mathrm{Cl}: 1.76-4.72, \mathrm{P}<0.00001)$ (Fig. $3 \mathrm{H})$. In contrast, patients with other distant metastasis $(\mathrm{OR}=1.34$, 95\% Cl: 0.47-3.79, $P=0.58)$ (Fig. 3F) and ECOG scale (OR=1.30, 95\% Cl: 0.89-1.91, $P=0.17$ ) (Fig. 3I) did not show significant differences between two groups. Furthermore, a fixed-effects model was utilized considering no obvious sample heterogeneity in the above studies while a random-effexts model was used for studies with obvious heterogeneity.

\section{Meta-analysis of clinical laboratory parameters}

The results showed NSCLC patients had higher levels of CEA (WMD $=10.94,95 \% \mathrm{Cl}: 7.47-14.40, P<0.00001)$ (Fig. 4A), CA199 $(\mathrm{WMD}=20.23,95 \% \mathrm{Cl}: 12.20-28.26, P<0.0001)$ (Fig. 4B), CYFRA211 (WMD=1.78, 95\%Cl: 0.04-3.51, $P=0.04)$ (Fig. 4C), NSE (WMD=9.66, 95\%Cl: 6.18-13.14, $P<0.00001$ ) (Fig. 4D) and CA125 (WMD=22.39, 95\%Cl: 9.79-34.98, $P=0.0005$ ) (Fig. 4E). Obvious heterogeneity was observed among these five indexes $(I 2 \$ 50 \% ; P<0.05)$, thus, a random-effects model was utilized.

\section{Meta-analysis of survival rates}

Eight studies assessed the survival rates. The resulted indicated that, as time goes on, the survival rates at 1-, 2-, 3-, 5-year of BM with NSCLC patients were significantly decreased compared to that of NSCLC patients $(P<0.05)$ (Fig. 5).

\section{Sensitivity analysis and risk of bias}

The Newcastle-Ottawa Quality Assessment scales (Table 1) and GRADE evaluation (Fig. 6, Fig. 7) indicated that the included studies were of acceptable quality. Risk of bias was summarized and evaluated in Fig. 8 and Fig.9. A sensitivity analysis was conducted to evaluate the influence of each included study, the results showed that heterogeneity and the pooled ORs or WMDs of BM were not significantly altered by any single study, indicating that our conclusions are relatively reliable. Funnel plot were generated for the indexes and further shown in Supplementary Fig. S1.

\section{Discussion}


Our meta-analysis of individual 43 studies incorporating 11415 participants assessed the risk factors and prognosis of BM in NSCLC patients. Our findings might be important in the prevention and evaluation of NSCLC patients with BM. The results were divided into four categories: clinical characteristics, tumor-related indexes, clinical laboratory parameters and survival rates of patients.

By summarizing all relevant studies, we found female, adenocarcinoma or non-squamous cell carcinoma, advanced tumor stage, node stage, 1ymphatic metastasis, EGFR gene mutation, KRAS gene mutation, and higher levels of CEA, CA199, CYFRA211, NSE and CA125 were clinical risk factors which can predict BM.

Some multivariate analyses have already showed the risk of BM was reduced with age, but our meta-analysis found that age 60 years old or younger was associated with the incidence of BM. The reason why an increased risk in the younger age group remains unclear, the possible mechanism maybe due to the differential expression of some biological markers associated with BM such as Ecadherin and Caspase-3 between younger and older patients. ${ }^{57}$ It is well known that adenocarcinoma is common in female and commonly metastasize to the brain, which may explain why female have a higher incidence of BM. ${ }^{24}$ Moreover, a recent study ${ }^{58}$ showed that the proportion of lung cancers diagnosed among smokers is increasing, the risk of developing lung cancer is 20-40 times higher in smokers compared to never-smokers, which may explain why a high proportion of smoking history in NSCLC patients with BM.

BM is closely related to tumor-related indicators. In 2015, Won et al ${ }^{59}$ established a nomogram for predicting BM in NSCLC patients, he found histological type, $T$ stage and $N$ stage were closely linked to BM. Similarly, Wang et al ${ }^{60}$ considered non-squamous cell carcinoma and multiple 1ymphatic metastasis were both risk factors for BM, which was also supported by our study. We found nonsquamous cell carcinoma, especially adenocarcinoma was an independent risk factor for BM, which may be attributed to the invasive growth of adenocarcinoma. Previous research ${ }^{61}$ guessed if tumor spread to the lymphatic system of the chest, it will also involve the distant metastasis of other organs (including bone, liver and kidney) and if distant metastasis happened, the probability of BM will increase. Our study is consistent with these studies in identifying 1ymphatic metastasis as significant prognostic factor. A meta-analysis involving 22 studies has reported that patients with EGFR mutation type were more susceptible to develop into BM than those with EGFR wild type $(\mathrm{OR}=1.99$, $95 \otimes \mathrm{Cl}: 1.59-2.48, P=0.000) .{ }^{62}$ The possible mechanism may involve EGFR activating MET via protein kinases and activating STAT3 via interleukin-6 to promote BM in NSCLC. ${ }^{63,64}$

Besides, our study found the levels of relevant serum tumor markers were related to BM in NSCLC patients. We identified five prognostic factors: higher levels of CEA, CA199, CYFRA211, NSE and CA125. It has been reported that CEA-positive tumor cells are more easier to cross the blood-brain barrier and adhere to the cerebral vasculature, which is beneficial to the occurrence of BM. ${ }^{65}$ Our study also found that higher level of CEA was a risk factor for BM. Meanwhile, previous studies ${ }^{45,49}$ demonstrated the level of serum CEA, CA199, CA125 and CYFRA211 were higher than that in the BM group than the control group, providing an important reference for early detection of BM in NSCLC.

The results of cohort studies and case-control studies have also been analyzed separately (Table 2). The statistical results based on cohort studies were consistent with the results based on case-control studies except the distant metastasis. Considering cohort studies had a more proportion and were more likely to be authentic, we think these two indexes were also probably significant risk factors for BM now. Moreover, the heterogeneity of five serum tumor markers was all significant $(P<0.05)$, which may be attributable to failure to publish studies with negative results or different measuring means. And then we found there were only case-control studies for some indexes after stratified by study design, which needs more studies to confirm the conclusion.

In addition, we assessed the differences in survival rates at 1-, 2-, 3-, 5-year respectively between BM with NSCLC patients and sample NSCLC patients. The results indicated that the former group had a significantly lower survival rate $(P<0.05)$. On one hand, patients with $\mathrm{BM}$ are more likely to combine with distant metastasis of other sites, increasing the mortality of patients. On the other hand, as the results shown in above, NSCLC patients with an advanced tumor stage were easier to combine with BM, which can also decrease the survival time of NSCLC patients.

Our study inevitably had some shortcomings and omissions. First, the studies included in our meta-analysis were all cohort or casecontrol studies and the quality assessment by the NOS showed that the 34 included studies had relatively low scores (5 8), indicating that the results may have been subject to selection bias. Second, potential risk factors such as cancer history, treatment approach or other biological markers could also promote the occurrence of BM and affect the prognosis of cancers, which cannot be 
explored because the studies included may not be enough to provide the information required. Third, funnel plots showed there was no obvious publication bias for indexes with more than 10 relevant studies, but we considered that potential bias couldn't be completely excluded for indexes with fewer than 10 studies.

\section{Conclusions}

In summary, our meta-analysis revealed that NSCLC patients with BM have some different clinical features, including female, adenocarcinoma or non-squamous cell carcinoma, advanced tumor stage, node stage, 1ymphatic metastasis, EGFR gene mutation, KRAS gene mutation and higher levels of CEA, CA199, CYFRA211, NSE and CA125. Moreover, the presence of BM could significantly decrease the survival time of NSCLC patients, indicating a poor survival prognosis. The meta-analysis demonstrated that NSCLC patients with BM have more aggressive clinical features and a poor survival prognosis.

\section{Abbreviations}

$\mathrm{BM}$, brain metastasis; NSCLC, non-small cell lung cancer; CT, computed tomography; MRI, magnetic resonance imaging; PET, positron emission tomography; T, tumor; N, node; EGFR, epidermal growth factor receptor; KRAS, kirsten rat sarcoma viral oncogene; CEA, carcinoembryonic antigen; CA199, carbohydrate antigen 199; CYFRA21-1, cytokeratin-19 fragment; NSE, neuron-specific enolase; CA125, carbohydrate antigen 125; NOS, Newcastle Ottawa Quality Assessment Scale; OR, odds ratio; WMD, weighted mean difference; $\mathrm{Cl}$, confidence interval.

\section{Declarations}

\section{Ethics approval and consent to participate}

Not applicable.

\section{Consent for publication}

Not applicable.

\section{Availability of data and materials}

Data sharing is not applicable to this article as no datasets were generated or analyzed during the current study.

\section{Funding}

Not applicable.

\section{Competing interest}

The authors declare that they have no competing interests.

\section{Authors' contributions}

Shanshan Chen and Xin Hua designed the study; Hongming Zhang and Xiaolizhu provided substantial conception; Shuhua Han, Jinfang Jia and Lu Xu collected the data; Shuzhen Wei and Ying Wu performed the statistical analysis and wrote the first draft of the manuscript; All authors (Shanshan Chen, Xin Hua, Jinfang Jia, Ying Wu, Shuzhen Wei, Lu Xu, Shuhua Han, Hongming Zhang, Xiaoli Zhu) contributed to the interpretation of the results and critically reviewed the first draft of the manuscript. All authors gave final approval for submission of the manuscript.

\section{Acknowledgements}

Since the novel coronavirus spread in China and worldwide, all authors rushed to the forefront of fighting against the virus. Missions in the heart, responsibility in the shoulder. We extend our highest thanks to all authors' families, teachers and colleagues, for supporting us during the hard time. 


\section{Reference}

1. Torre LA, Siegel RL, Jemal A. Lung Cancer Statistics. In: Ahmad A, Gadgeel S, eds. Lung Cancer and Personalized Medicine: Current Knowledge and Therapies. Cham: Springer International Publishing; 2016:1-19.

2. LI Rui-yang CD. Analysis of Related Factors of Brain Metastasis in Lung Cancer. World Latest Medicine Information. 2018;18(72):151-152.

3. Waqar SN, Samson PP, Robinson CG, et al. Non-small-cell Lung Cancer With Brain Metastasis at Presentation. Clinical lung cancer. Jul 2018;19(4):e373-e379.

4. Daniel Morgensztern SHN, Feng Gao, Ramaswamy Govindan. Trends in Stage Distribution for Patients with Non-small Cell Lung Cancer: A National Cancer Database Survey. Journal of Thoracic Oncology. 2010;5(1):29-33.

5. Ando T, Kage H, Saito M, et al. Early stage non-small cell lung cancer patients need brain imaging regardless of symptoms. International journal of clinical oncology. Aug 2018;23(4):641-646.

6. Petrovic M, llic N, Loncarevic 0 , et al. Risk factors for brain metastases in surgically staged IIIA non-small cell lung cancer patients treated with surgery, radiotherapy and chemotherapy. Vojnosanitetski pregled. Aug 2011;68(8):643-649.

7. Xie SS, Li M, Zhou CC, Song XL, Wang CH. Prophylactic cranial irradiation may impose a detrimental effect on overall survival of patients with nonsmall cell lung cancer: a systematic review and meta-analysis. PloS one. 2014;9(7):e103431.

8. Cagney DN, Martin AM, Catalano PJ, et al. Incidence and prognosis of patients with brain metastases at diagnosis of systemic malignancy: a population-based study. Neuro-oncology. Oct 19 2017;19(11):1511-1521.

9. Soffietti R, Kocher M, Abacioglu UM, et al. A European Organisation for Research and Treatment of Cancer phase III trial of adjuvant whole-brain radiotherapy versus observation in patients with one to three brain metastases from solid tumors after surgical resection or radiosurgery: quality-of-life results. Journal of clinical oncology : official journal of the American Society of Clinical Oncology. Jan 1 2013;31(1):65-72.

10. Stang A. Critical evaluation of the Newcastle-Ottawa scale for the assessment of the quality of nonrandomized studies in metaanalyses. European journal of epidemiology. Sep 2010;25(9):603-605.

11. Guyatt GH, Oxman AD, Kunz R, et al. What is "quality of evidence" and why is it important to clinicians? Bmj. May 3 2008;336(7651):995-998.

12. Asimit J, Day-Williams A, Zgaga L, Rudan I, Boraska V, Zeggini E. An evaluation of different meta-analysis approaches in the presence of allelic heterogeneity. European journal of human genetics : EJHG. Jun 2012;20(6):709-712.

13. Li SJ, Huang J, Zhou XD, Zhang WB, Lai YT, Che GW. Clinicopathological and prognostic significance of Oct-4 expression in patients with non-small cell lung cancer: a systematic review and meta-analysis. Journal of thoracic disease. Jul 2016;8(7):1587-1600.

14. Bajard A, Westeel V, Dubiez A, et al. Multivariate analysis of factors predictive of brain metastases in localised non-small cell lung carcinoma. Lung cancer. Sep 2004;45(3):317-323.

15. Carolan H, Sun AY, Bezjak A, et al. Does the incidence and outcome of brain metastases in locally advanced non-small cell lung cancer justify prophylactic cranial irradiation or early detection? Lung cancer. Jul 2005;49(1):109-115.

16. Arrieta $\mathrm{O}$, Saavedra-Perez D, Kuri R, et al. Brain metastasis development and poor survival associated with carcinoembryonic antigen (CEA) level in advanced non-small cell lung cancer: a prospective analysis. BMC cancer. Apr 22 2009;9:119.

17. LIANG Ying LY, ZHANG LI, WANG Siyu, WU Haiying, CHEN Likun, LI Mingyi, XU Guangchuan, RONG Tiehua, HE Youjian. Clinical Predictive Factors for Brain Metastasis from Stage IIIA Non-Small-Cell Lung Cancer after Surgery. CHINESE JOURNAL OF CLINICAL ONCOLOGY. 2010;37(21):1232-1236.

18. Huang Shuai QY. Study on Correlation between Non-small Cell Lung Cancer, Brain, Bone Metastasis and Tumor Markers [dissertation]. China: Shandong Traditional Chinese Medicine University. 2010.

19. Dimitropoulos C, Hillas G, Nikolakopoulou S, et al. Prophylactic cranial irradiation in non-small cell lung cancer patients: who might be the candidates? Cancer management and research. 2011;3:287-294.

20. Jie C. Evaluation of risk factors for brain metastasis and the effect of targeted therapy in non-small cell lung cancer patients with brain metastases [dissertation]. China: Qinghua medical University. 2012. 
21. Xiao D. Risk factors of brain metastases in non-small cell lung cancer [dissertation]. China: Chinese Academy of Medical Sciences \& Peking Union Medical College. 2012.

22. Liu F JJ, Gong ZQ, Li HY. Analysis of related factors of brain metastasis in locally advanced non-small cell lung cancer. MODERN JOURNAL OF INTEGRATED TRADITIONAL CHINESE AND WESTERN MEDCINE. 2012;21(36):4018-4019.

23. Cao Xia WA, Yang Bei, Yuan Yuan, Wu Shengqi, Luo Rongxi. Study on risk factors of brain metastases of locally advanced nonsmall-cell lung cancer. Cancer Research and Clinic. 2012;24(1):24-27.

24. Cui Li YJ, Zhang Jianqing, Yang Mei, Ma Lili, Zhang Li. High risk factors and survival analysis of brain metastasis in non-small cell lung cancer. Journal of Practical Oncology. 2013;28(1):45-48.

25. Hsiao SH, Chung CL, Chou YT, Lee HL, Lin SE, Liu HE. Identification of subgroup patients with stage IIIB/IV non-small cell lung cancer at higher risk for brain metastases. Lung cancer. Nov 2013;82(2):319-323.

26. Ji Z, Bi N, Wang J, et al. Risk factors for brain metastases in locally advanced non-small cell lung cancer with definitive chest radiation. International journal of radiation oncology, biology, physics. Jun 1 2014;89(2):330-337.

27. Toshihiko luchi MS, Meiji Itakura, Sana Yokoi, Yasumitsu Moriya, Hajime Tamura, Yasushi Yoshida, Hironori Ashinuma, Koichiro Kawasaki, Yuzo Hasegawa, Tsukasa Sakaida, Toshihiko lizasa. Frequency of brain metastases in non-small-cell lung cancer, and their association with epidermal growth factor receptor mutations. Japan Society of Clinical Oncology. 2014;20:674-679.

28. Zhang Weihua YM, Zhou Rongwei, Sun jian. Analysis of clinical characteristics and risk factors of brain metastasis in stage IIIA non-small cell lung cancer after complete resection. Chinese Journal of Gerontology. 2014;34(1):107-108.

29. Li Zhijian LZ, Lu Qiang, Wang Yan, Wang Weifeng, Zu Chao. Clinical significance of combined detection of CA19-9, CA125, CEA and Ferritin in the diagnosis of NSCLC with brain or bone Metastasis. Progress in Modern Biomedicine. 2014;14(19):3729-3732.

30. Zhao Wenhua LY, Yu Qitao, Zhou Shaozhang, Song Xiangqun. Analysis of the relationship between serum CEA level and brain metastasis in patients with advanced non-small cell lung cancer. Journal of Guangxi Medical University. 2015;32(3):401-404.

31. Hui Y. Relevant clinical and imaging predictors of metastatic disease to the brain from non-small cell lung carcinoma [dissertation]. China: Jinan University. 2015.

32. Yanping L. Risk factors for brain metastases in advanced non-small cell lung cancer [dissertaiton]. China: Guangxi Medical University. 2015.

33. Zhou Jiupeng WL, Yang Haixia, Sun Hong. The risk factors of brain metastases in non-small cell Lung cancer patients after complete resection. Journal of Kunming Medical University. 2015;36(10):138-141.

34. Xing Zuo WH, Hu qun, Zhao Haiyan, Su wuyun. Risk factors and survival analysis of locally advanced non-small cell lung cancer with brain metastasis. Journal of Clinical Medicine in Practice. 2015;19(23):24-27.

35. Zheng Yuzhu ZX, Li Hao. Risk factor analysis for postoperative brain metastasis in patients with non-small-cell lung cancer. Journal of Medical Postgraduates. 2015;28(9):953-956.

36. Haiyan Z. Risk factors for brain metastases after prophylactic cranial irradiation in non-small cell cancer [dissertaiton]. China: Jinan Universtiy. 2015.

37. Hsu F, De Caluwe A, Anderson D, Nichol A, Toriumi T, Ho C. EGFR mutation status on brain metastases from non-small cell lung cancer. Lung cancer. Jun 2016;96:101-107.

38. Hendriks LEL, Brouns JWM, Amini M, et al. Development of symptomatic brain metastases after chemoradiotherapy for stage III non-small cell lung cancer: Does the type of chemotherapy regimen matter? Lung cancer. Nov 2016;101:68-75.

39. Zhang F, Zheng W, Ying L, et al. A Nomogram to Predict Brain Metastases of Resected Non-Small Cell Lung Cancer Patients. Annals of surgical oncology. Sep 2016;23(9):3033-3039.

40. Koh YW, Choi JH, Ahn MS, Choi YW, Lee HW. Baseline neutrophil-lymphocyte ratio is associated with baseline and subsequent presence of brain metastases in advanced non-small-cell lung cancer. Scientific reports. Dec 7 2016;6:38585.

41. Chen La ZX, Jiang Feng, Le Hanbo, Liu Xiaoguang, Zhu Wangyu. Diagnosis and prognosis of brain metastasis in lung cancer by tumor marker D-dimer and platelet count. Zhejiang Clinical Medical Journal. 2016;18(6):1011-1013.

42. Duan Meimei FJ. Value of CA125, CEA, CA724 and P53 expression in diagnosis of NSCLC with brain metastases. Modern Hospital. 2016;16(11):1611-1613.

43. Pascale Tomasini CS, Nataliya Khobta, Philippe Metellus, L'Houcine Ouafik, Isabelle Nanni, Laurent Greillier, Anderson Loundou, Frederic Fina, Celine Mascaux, Fabrice Barlesi. EGFR and KRAS Mutations Predict the Incidence and Outcome of Brain

Page $8 / 21$ 
Metastases in Non-Small Cell Lung Cancer. International Journal of Molecular Sciences. 2016;17:2132-2144.

44. Wei L. Prediction effect of NSE to brain mestastasis in patients with non-small cell lung cancer before treatment and living condition. Medical Laboratory Science and Clinics. 2017;28(4):12-15.

45. Fang L. Joint detection of serum tumor markers in the diagnosis and treatment of non-small cell lung cancer with brain metastases. The Practical Journal of Cancer. The Practical Journal of Cancer. 2017;32(4):578-581.

46. Gong Qinghong LY, Gu Xiaoqiong. Correlations analysis between serum tumor marker with clinical pathology, short-term effect and prognosis of NSCLC patients with brain metastases. Med \& Pharm J Chin PLA. 2017;29(9):31-35.

47. Dai Chengyan WL, Yao Dongmei, Hai Xuying, Han Dong, Zhao Min. Analysis of characteristics and risk factors of brain metastases following thoracic radiotherapy in surgery-ineligible patients with locally advanced non-small cell lung cancer. ONCOLOGY PROGRESS. 2017;15(312-333).

48. Chang WY, Wu YL, Su PL, Yang SC, Lin CC, Su WC. The impact of EGFR mutations on the incidence and survival of stages I to III NSCLC patients with subsequent brain metastasis. PloS one. 2018;13(2):e0192161.

49. Zhao Xiaoli KX, Shi Mengyuan, Zhou Kun, Yang Shuangning, Yan Yan, Wang Liping. Application value of combined detection of four serum tumor markers in the diagnosis of brain metastasis of non-small cell lung cancer. Journal of Basic and Clinical Oncology. 2018;31(1):57-59.

50. Li Miao LC. Risk factors of brain metastasis in patients with non-small cell lung cancer. Journal of Logistics University of PAP (Medical Sciences). 2018;27(12):999-1002.

51. Tongchen H. Analysis of Risk Factors of Brain Metastasis in Patients with Advanced NSCLC. The Practical Journal of Cancer. 2018;33(11):1885-1889.

52. ZHOU Zheng FQ. Correlation between brain metastasis and serum tumor markers in patients with non-small cell lung cancer. Chinese Journal of Practical Nervous Diseases. 2019;22(19):2097-2103.

53. LIU Juan LX, CHEN Juan, YU Danfeng. A correlation analysis between brain metastases from lung cancer and serum NSE expression in patients. Chinese Journal of Surgical Oncology. 2019;11(6):446-449.

54. LIU Shuang LX. The clinical diagnostic value of joint detection of multiple tumor markers in the NSCLC patients with brain metastasis. JOURNAL OF NORTH SICHUAN MEDICAL COLLEGE. 2019;34(5):548-550.

55. Xin C. Analysis of risk factors of brain metastases in advanced non-small cell lung cancer [dissertation]. China: China Medical University. 2019.

56. HU Liping ZF, FANG Changlian, WANG Suoyu, HUANG Chuansheng, HUANG guangming, HUANG Jian, JIANG Feng, LIU Minzhi, XU Yanliang. Risk Analysis Brain Metastasis of Non-small Cell Lung Cancer (NSCLC) in Combination with Image Feature, Pathological Pattern and Ki-67 Gene Expression. The Practical Journal of Cancer. 2019;34(2):219-221.

57. Saad AG, Yeap BY, Thunnissen FB, et al. Immunohistochemical markers associated with brain metastases in patients with nonsmall cell lung carcinoma. Cancer. Oct 15 2008;113(8):2129-2138.

58. Chen YX, Guo Y, Dong SS, et al. Runs of homozygosity associate with decreased risks of lung cancer in never-smoking East Asian females. Journal of Cancer. 2018;9(21):3858-3866.

59. Won YW, Joo J, Yun T, et al. A nomogram to predict brain metastasis as the first relapse in curatively resected non-small cell lung cancer patients. Lung cancer. May 2015;88(2):201-207.

60. Wang SY, Ye X, Ou W, Lin YB, Zhang BB, Yang H. Risk of cerebral metastases for postoperative locally advanced non-small-cell lung cancer. Lung cancer. May 2009;64(2):238-243.

61. Mujoomdar A, Austin JH, Malhotra R, et al. Clinical predictors of metastatic disease to the brain from non-small cell lung carcinoma: primary tumor size, cell type, and lymph node metastases. Radiology. Mar 2007;242(3):882-888.

62. Li L, Luo S, Lin H, et al. Correlation between EGFR mutation status and the incidence of brain metastases in patients with nonsmall cell lung cancer. Journal of thoracic disease. Aug 2017;9(8):2510-2520.

63. Breindel JL, Haskins JW, Cowell EP, Zhao M, Nguyen DX, Stern DF. EGF receptor activates MET through MAPK to enhance nonsmall cell lung carcinoma invasion and brain metastasis. Cancer research. Aug 15 2013;73(16):5053-5065.

64. Gao SP, Mark KG, Leslie K, et al. Mutations in the EGFR kinase domain mediate STAT3 activation via IL-6 production in human lung adenocarcinomas. The Journal of clinical investigation. Dec 2007;117(12):3846-3856. 
65. Liu ZJ SQ, Lu B, Zhang Z, Tian CL. Conventional Tumor Markers in Cerebralspinal Fluid in Patients with Elevated Serum Tumor Markers and without Central Nervous System Malignant Diseases. Zhongguo Yi Xue Ke Xue Yuan Xue Bao. 2016;38(5):539-542.

\section{Tables}


Table 1:

Basic characteristics of the retrieved studies.

\begin{tabular}{|c|c|c|c|c|c|c|c|c|c|}
\hline Study & Year & Country & Gender(M/F) & Age & BM/total & Ad/other & BM diagnosis & $\begin{array}{l}\text { Study } \\
\text { design }\end{array}$ & NOS \\
\hline Bajard et al ${ }^{14}$ & 2004 & France & $279 / 26$ & $62(33-88)$ & $77 / 305$ & $87 / 218$ & $\mathrm{CT}$ & Cohort & 8 \\
\hline $\begin{array}{l}\text { Carolan et } \\
\mathrm{al}^{15}\end{array}$ & 2005 & Canada & $47 / 36$ & NM & $29 / 83$ & NM & NM & Cohort & 6 \\
\hline Arrieta et al ${ }^{16}$ & 2009 & Mexico & $164 / 129$ & $60.7 \pm 0.7$ & $170 / 293$ & $190 / 103$ & CT & Cohort & 8 \\
\hline L Y et al ${ }^{17}$ & 2010 & China & $132 / 61$ & $58(31-77)$ & $67 / 193$ & NM & $\mathrm{MRI} / \mathrm{CT}$ & Cohort & 6 \\
\hline H S et al ${ }^{18}$ & 2010 & China & $74 / 50$ & $\begin{array}{l}59.81(40- \\
75)\end{array}$ & $35 / 124$ & $73 / 51$ & MRI/CT/PET & $\begin{array}{l}\text { Case } \\
\text { control }\end{array}$ & 6 \\
\hline $\begin{array}{l}\text { Dimitropoulos } \\
\text { et al }{ }^{19}\end{array}$ & 2011 & Greece & $143 / 18$ & $65.1 \pm 8.9$ & $39 / 161$ & $59 / 102$ & CT & Cohort & 5 \\
\hline $\mathrm{C} \mathrm{J}$ et $\mathrm{al}^{20}$ & 2012 & China & $63 / 47$ & $63(38-86)$ & $22 / 110$ & $51 / 59$ & MRI/CT/PET & $\begin{array}{l}\text { Case } \\
\text { control }\end{array}$ & 6 \\
\hline D X et $\mathrm{al}^{21}$ & 2012 & China & $156 / 61$ & $60(27-79)$ & $53 / 217$ & $112 / 105$ & $\mathrm{MRI} / \mathrm{CT}$ & Cohort & 5 \\
\hline L F et $\mathrm{al}^{22}$ & 2012 & China & $62 / 41$ & $58.6 \pm 14.9$ & $41 / 103$ & NM & MRI & Cohort & 7 \\
\hline$C X$ et $a^{23}$ & 2012 & China & $94 / 20$ & NM & $36 / 114$ & $35 / 79$ & NM & Cohort & 5 \\
\hline$C L$ et $a^{24}$ & 2013 & China & $95 / 55$ & $60.42 \pm 11.33$ & $100 / 150$ & $61 / 89$ & NM & $\begin{array}{l}\text { Case } \\
\text { control }\end{array}$ & 6 \\
\hline Hsiao et $a^{25}$ & 2013 & China & $271 / 211$ & $67.5 \pm 13.4$ & $173 / 482$ & $369 / 113$ & $\mathrm{MRI} / \mathrm{CT}$ & Cohort & 7 \\
\hline Ji Z et $\mathrm{al}^{26}$ & 2014 & China & $286 / 60$ & NM & $74 / 346$ & NM & $\mathrm{MRI} / \mathrm{CT}$ & Cohort & 8 \\
\hline luchi et $a^{27}$ & 2014 & Japan & $735 / 392$ & $67(30-93)$ & $154 / 1127$ & $895 / 232$ & MRI & Cohort & 6 \\
\hline$Z$ WH et $\mathrm{al}^{28}$ & 2014 & China & $132 / 61$ & $59.5 \pm 4.5$ & 77/193 & NM & $\mathrm{CT}$ & Cohort & 7 \\
\hline L ZJ et $\mathrm{al}^{29}$ & 2014 & China & $116 / 68$ & $58.43 \pm 12.68$ & $96 / 184$ & $86 / 98$ & MRI/CT/PET & $\begin{array}{l}\text { Case } \\
\text { control }\end{array}$ & 7 \\
\hline$Z$ WH et $\mathrm{al}^{30}$ & 2015 & China & $86 / 72$ & $55(28-80)$ & $62 / 158$ & $112 / 46$ & CT & Cohort & 5 \\
\hline Y H et $\mathrm{al}^{31}$ & 2015 & China & $175 / 97$ & $57(31-82)$ & $78 / 272$ & $93 / 179$ & MRI & $\begin{array}{l}\text { Case } \\
\text { control }\end{array}$ & 8 \\
\hline$Z$ JP et $\mathrm{al}^{33}$ & 2015 & China & $146 / 68$ & $63(25-77)$ & $121 / 214$ & NM & MRI/CT & $\begin{array}{l}\text { Case } \\
\text { control }\end{array}$ & 6 \\
\hline L YP et $\left.a\right|^{32}$ & 2015 & China & $72 / 80$ & $55(28-80)$ & $62 / 158$ & $112 / 46$ & MRI/CT & $\begin{array}{l}\text { Case } \\
\text { control }\end{array}$ & 6 \\
\hline$X Z$ et $a^{34}$ & 2015 & China & $78 / 46$ & $63 \rrbracket 55-80 \rrbracket$ & $51 / 124$ & $65 / 59$ & NM & $\begin{array}{l}\text { Case } \\
\text { control }\end{array}$ & 6 \\
\hline $\mathrm{Z} Y \mathrm{Y}$ et $\mathrm{al}^{35}$ & 2015 & China & $147 / 66$ & $56.7 \pm 18.3$ & $51 / 213$ & $96 / 117$ & MRI/CT & Cohort & 5 \\
\hline Z HY et al ${ }^{36}$ & 2015 & China & $129 / 46$ & $55(29-76)$ & $36 / 175$ & NM & MRI/CT & Cohort & 7 \\
\hline Hsu et $\mathrm{al}^{37}$ & 2016 & Canada & $216 / 327$ & $66 \llbracket 58-74 \rrbracket$ & $143 / 543$ & NM & $\mathrm{MRI} / \mathrm{CT}$ & Cohort & 6 \\
\hline $\begin{array}{l}\text { Hendriks et } \\
\mathrm{al}^{38}\end{array}$ & 2016 & Holland & $535 / 303$ & $63 \pm 10$ & $153 / 838$ & $324 / 514$ & MRI/PET & Cohort & 5 \\
\hline Zhang et $\mathrm{al}^{39}$ & 2016 & China & $486 / 151$ & $60(30-82)$ & NM/637 & $305 / 332$ & NM & Cohort & 5 \\
\hline
\end{tabular}




\begin{tabular}{|c|c|c|c|c|c|c|c|c|c|}
\hline Koh et $\mathrm{al}^{40}$ & 2016 & Korea & $166 / 94$ & $59.5(30-84)$ & $94 / 260$ & $194 / 66$ & $\mathrm{MRI} / \mathrm{CT}$ & Cohort & 8 \\
\hline$C L$ et $a l^{41}$ & 2016 & China & $51 / 16$ & NM & $27 / 67$ & NM & $\mathrm{MRI} / \mathrm{CT}$ & $\begin{array}{l}\text { Case } \\
\text { control }\end{array}$ & 5 \\
\hline D MM et $\mathrm{al}^{42}$ & 2016 & China & $55 / 27$ & $31-81$ & $41 / 82$ & NM & NM & $\begin{array}{l}\text { Case } \\
\text { control }\end{array}$ & 5 \\
\hline $\begin{array}{l}\text { Tomasini et } \\
\mathrm{al}^{43}\end{array}$ & 2016 & France & $94 / 48$ & $62(31-88)$ & $81 / 142$ & NM & NM & Cohort & 6 \\
\hline L W 44 & 2017 & China & $95 / 53$ & $61.2 \pm 5.8$ & $35 / 148$ & $103 / 45$ & NM & Cohort & 7 \\
\hline$L^{4} 45$ & 2017 & China & $84 / 64$ & NM & $47 / 148$ & $108 / 40$ & MRI/CT/PET & $\begin{array}{l}\text { Case } \\
\text { control }\end{array}$ & 5 \\
\hline $\mathrm{G}$ QH et al ${ }^{46}$ & 2017 & China & $86 / 42$ & $56.86 \pm 9.88$ & $62 / 128$ & $92 / 36$ & $\mathrm{MRI} / \mathrm{CT}$ & $\begin{array}{l}\text { Case } \\
\text { control }\end{array}$ & 7 \\
\hline D CY et al ${ }^{47}$ & 2017 & China & $40 / 32$ & $49.26 \pm 10.36$ & $15 / 72$ & NM & $\mathrm{MRI} / \mathrm{CT}$ & Cohort & 6 \\
\hline Chang et al ${ }^{48}$ & 2018 & China & $250 / 241$ & NM & $78 / 491$ & $444 / 47$ & $\mathrm{MRI} / \mathrm{CT}$ & Cohort & 8 \\
\hline$Z X L$ et $a^{49}$ & 2018 & China & $66 / 66$ & $38-82$ & $65 / 132$ & $91 / 41$ & $\mathrm{MRI} / \mathrm{CT}$ & $\begin{array}{l}\text { Case } \\
\text { control }\end{array}$ & 6 \\
\hline L M et $a l^{50}$ & 2018 & China & $88 / 65$ & NM & $41 / 153$ & $123 / 30$ & MRI/CT & $\begin{array}{l}\text { Case } \\
\text { control }\end{array}$ & 6 \\
\hline H TC et al ${ }^{51}$ & 2018 & China & $57 / 103$ & $58.21 \pm 11.73$ & $41 / 160$ & $96 / 41$ & $\mathrm{MRI} / \mathrm{CT}$ & Cohort & 7 \\
\hline$Z$ Z et $a^{52}$ & 2019 & China & $80 / 55$ & $62.8 \pm 2.8$ & $57 / 135$ & 79/191 & $\mathrm{MRI} / \mathrm{CT}$ & $\begin{array}{l}\text { Case } \\
\text { control }\end{array}$ & 6 \\
\hline $\mathrm{L} J$ et $\left.a\right|^{53}$ & 2019 & China & NM & $51.85 \pm 13.73$ & $51 / 125$ & NM & $\mathrm{MRI} / \mathrm{CT}$ & $\begin{array}{l}\text { Case } \\
\text { control }\end{array}$ & 6 \\
\hline L S et al ${ }^{54}$ & 2019 & China & $74 / 46$ & NM & $40 / 80$ & NM & $\mathrm{MRI} / \mathrm{CT}$ & $\begin{array}{l}\text { Case } \\
\text { control }\end{array}$ & 5 \\
\hline$C X$ et $a^{55}$ & 2019 & China & $897 / 568$ & $25-84$ & $319 / 1465$ & $972 / 493$ & MRI/CT & Cohort & 8 \\
\hline H LP et al ${ }^{56}$ & 2019 & China & $84 / 26$ & $61 \pm 17$ & $27 / 110$ & $38 / 72$ & $\mathrm{MRI} / \mathrm{CT}$ & Cohort & 6 \\
\hline
\end{tabular}

Abbreviations: M/F, male/female; BM, brain metastasis; TNM, tumor node metastasis stage; Ad, adenocarcinoma; NOS, Newcastle Ottawa Quality Assessment Scale; MRI, magnetic resonance imaging; CT, computed tomography; PET, positron emission tomography; NM, not mentioned. 
Table 2:

The results stratified by study design for risk factors included in the meta-analysis

\begin{tabular}{|c|c|c|c|c|c|c|c|}
\hline \multirow[t]{2}{*}{ Study factors } & \multirow[t]{2}{*}{ Study type } & \multirow{2}{*}{$\begin{array}{l}\text { No. of } \\
\text { studies }\end{array}$} & \multirow{2}{*}{$\begin{array}{l}\text { OR }(95 \% \mathrm{Cl}) \text { or } \\
\text { WMD }(95 \% \mathrm{Cl})\end{array}$} & \multirow[t]{2}{*}{$\mathbf{P}$} & \multicolumn{2}{|c|}{ Heterogeneity } & \multirow{2}{*}{$\begin{array}{l}\text { Model } \\
\text { used }\end{array}$} \\
\hline & & & & & $I^{2}(\%)$ & $P_{h}$ & \\
\hline \multirow[t]{2}{*}{ Age } & cohort studies & 16 & $1.12(0.75-1.65)$ & 0.59 & $99 \%$ & $<0.00001$ & \multirow[t]{2}{*}{ Random } \\
\hline & $\begin{array}{l}\text { case-control } \\
\text { studies }\end{array}$ & 4 & $1.12(0.41-3.07)$ & 0.83 & $90 \%$ & $<0.00001$ & \\
\hline \multirow[t]{2}{*}{ Gender(Female) } & cohort studies & 15 & $1.37(1.20-1.55)$ & $<0.00001$ & $27 \%$ & 0.15 & \multirow[t]{2}{*}{ Fixed } \\
\hline & $\begin{array}{l}\text { case-control } \\
\text { studies }\end{array}$ & 9 & $1.12(1.05-1.21)$ & 0.001 & $31 \%$ & 0.17 & \\
\hline \multirow[t]{2}{*}{ A smoking history } & cohort studies & 9 & $1.11(0.67-1.84)$ & 0.67 & $80 \%$ & $<0.00001$ & \multirow[t]{2}{*}{ Random } \\
\hline & $\begin{array}{l}\text { case-control } \\
\text { studies }\end{array}$ & 7 & $1.02(0.74-1.41)$ & 0.90 & $25 \%$ & 0.24 & \\
\hline \multirow[t]{2}{*}{ A treatment history } & cohort studies & 2 & $0.94(0.60-1.48)$ & 0.80 & $0 \%$ & 0.56 & \multirow[t]{2}{*}{ Fixed } \\
\hline & $\begin{array}{l}\text { case-control } \\
\text { studies }\end{array}$ & 1 & $0.76(0.5-1.16)$ & 0.20 & - & - & \\
\hline \multirow[t]{2}{*}{ Adenocarcinoma } & cohort studies & 12 & $2.29(1.57-3.33)$ & $<0.00001$ & $79 \%$ & $<0.00001$ & \multirow[t]{2}{*}{ Random } \\
\hline & $\begin{array}{l}\text { case-control } \\
\text { studies }\end{array}$ & 10 & $2.52(1.97-3.23)$ & $<0.00001$ & $0 \%$ & 0.87 & \\
\hline \multirow{2}{*}{$\begin{array}{l}\text { Squamous cell } \\
\text { carcinoma }\end{array}$} & cohort studies & 8 & $0.30(0.21-0.41)$ & $<0.00001$ & $32 \%$ & 0.17 & \multirow[t]{2}{*}{ Random } \\
\hline & $\begin{array}{l}\text { case-control } \\
\text { studies }\end{array}$ & 9 & $0.48(0.28-0.8)$ & 0.001 & $74 \%$ & 0.0002 & \\
\hline \multirow[t]{2}{*}{ Tumor stage } & cohort studies & 10 & $1.24(0.89-1.73)$ & 0.20 & $75 \%$ & $<0.00001$ & \multirow[t]{2}{*}{ Random } \\
\hline & $\begin{array}{l}\text { case-control } \\
\text { studies }\end{array}$ & 4 & $1.84(1.17-2.89)$ & 0.009 & $44 \%$ & 0.15 & \\
\hline \multirow[t]{2}{*}{ Node stage } & cohort studies & 7 & $2.31(1.51-3.53)$ & 0.0001 & $73 \%$ & 0.001 & \multirow[t]{2}{*}{ Random } \\
\hline & $\begin{array}{l}\text { case-control } \\
\text { studies }\end{array}$ & 2 & $1.01(0.07-15.03)$ & 0.00 & $92 \%$ & 0.0004 & \\
\hline \multirow[t]{2}{*}{ 1ymphatic metastasis } & cohort studies & 2 & $3.24(1.96-5.36)$ & $<0.00001$ & $0 \%$ & 0.89 & \multirow[t]{2}{*}{ Fixed } \\
\hline & $\begin{array}{l}\text { case-control } \\
\text { studies }\end{array}$ & 1 & $2.17(1.03-4.56)$ & 0.04 & - & - & \\
\hline \multirow[t]{2}{*}{ Distant metastasis } & cohort studies & 2 & $0.87(0.12-6.39)$ & 0.89 & $92 \%$ & 0.0006 & \multirow[t]{2}{*}{ Random } \\
\hline & $\begin{array}{l}\text { case-control } \\
\text { studies }\end{array}$ & 2 & $2.01(0.29-13.86)$ & 0.05 & $94 \%$ & $<0.00001$ & \\
\hline \multirow[t]{2}{*}{ EGFR gene mutation } & cohort studies & 8 & $1.88(1.25-2.85)$ & 0.003 & $89 \%$ & $<0.00001$ & \multirow[t]{2}{*}{ Random } \\
\hline & $\begin{array}{l}\text { case-control } \\
\text { studies }\end{array}$ & 3 & $5.87(1.87-18.43)$ & 0.002 & $24 \%$ & 0.008 & \\
\hline \multirow[t]{2}{*}{ KRAS gene mutation } & cohort studies & 1 & $3.04(1.83-5.04)$ & $<0.00001$ & - & - & \multirow[t]{2}{*}{ Fixed } \\
\hline & $\begin{array}{l}\text { case-control } \\
\text { studies }\end{array}$ & 1 & $1.00(0.11-9.42)$ & 1.00 & - & - & \\
\hline ECOG scale $>2$ & cohort studies & 5 & $1.30(0.89-1.91)$ & 0.17 & $77 \%$ & 0.002 & Fixed \\
\hline CEA level & cohort studies & 2 & $\begin{array}{l}3.07(-10.70- \\
16.84)\end{array}$ & 0.66 & $99 \%$ & $<0.00001$ & Random \\
\hline
\end{tabular}




\begin{tabular}{|c|c|c|c|c|c|c|c|}
\hline & $\begin{array}{l}\text { case-control } \\
\text { studies }\end{array}$ & 9 & $1.68(1.04-2.31)$ & $<0.00001$ & $88 \%$ & $<0.00001$ & \\
\hline CA199 level & $\begin{array}{l}\text { case-control } \\
\text { studies }\end{array}$ & 7 & $\begin{array}{l}20.23(12.20- \\
28.26)\end{array}$ & $<0.0001$ & $94 \%$ & $<0.00001$ & Random \\
\hline CYFRA211 level & $\begin{array}{l}\text { case-control } \\
\text { studies }\end{array}$ & 4 & $1.78 \bowtie 0.04-3.51 \rrbracket$ & 0.04 & $92 \%$ & $<0.00001$ & Random \\
\hline \multirow[t]{2}{*}{ NSE level } & cohort studies & 1 & 7.73(4.48-10.98) & $<0.0001$ & - & - & \multirow[t]{2}{*}{ Random } \\
\hline & $\begin{array}{l}\text { case-control } \\
\text { studies }\end{array}$ & 2 & $5.42(-6.12-16.95)$ & 0.36 & $97 \%$ & $<0.00001$ & \\
\hline \multirow[t]{2}{*}{ CA125 level } & cohort studies & 1 & 7.67(4.63-10.71) & $<0.0001$ & - & - & \multirow[t]{2}{*}{ Random } \\
\hline & $\begin{array}{l}\text { case-control } \\
\text { studies }\end{array}$ & 7 & 24.7(8.45-40.95) & 0.003 & $98 \%$ & $<0.00001$ & \\
\hline
\end{tabular}

Abbreviations: OR, odds ratio; WMD, weighted mean difference; $\mathrm{Cl}$, confidence interval; EGFR, epidermal growth factor receptor; KRAS, kirsten rat sarcoma viral oncogene; CEA, carcinoembryonic antigen; CA199, carbohydrate antigen 199; CYFRA21-1, cytokeratin-19 fragment; NSE, neuron-specific enolase; CA125, carbohydrate antigen 125.

\section{Figures}

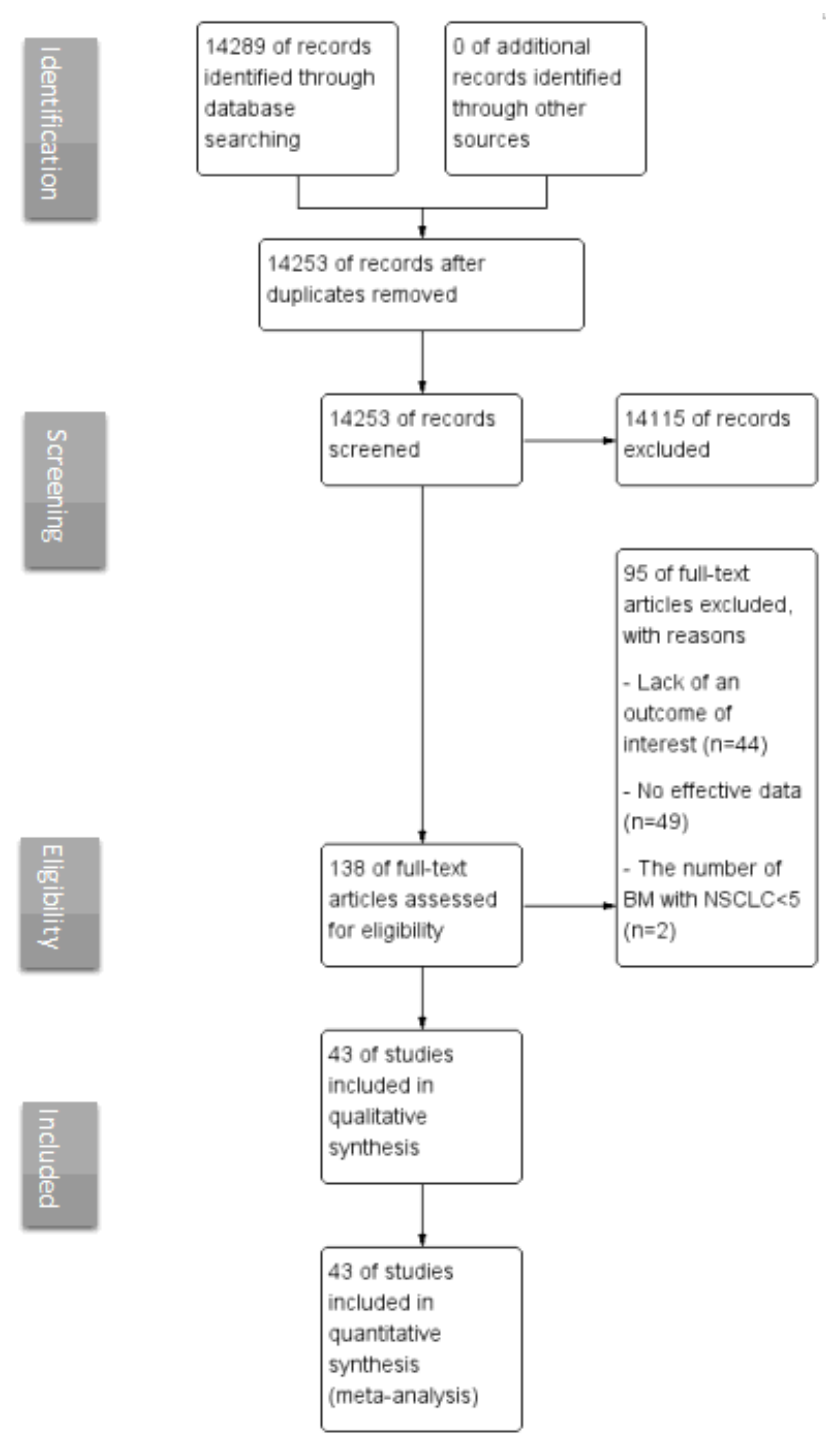

Figure 1 
Selection of the included studies.

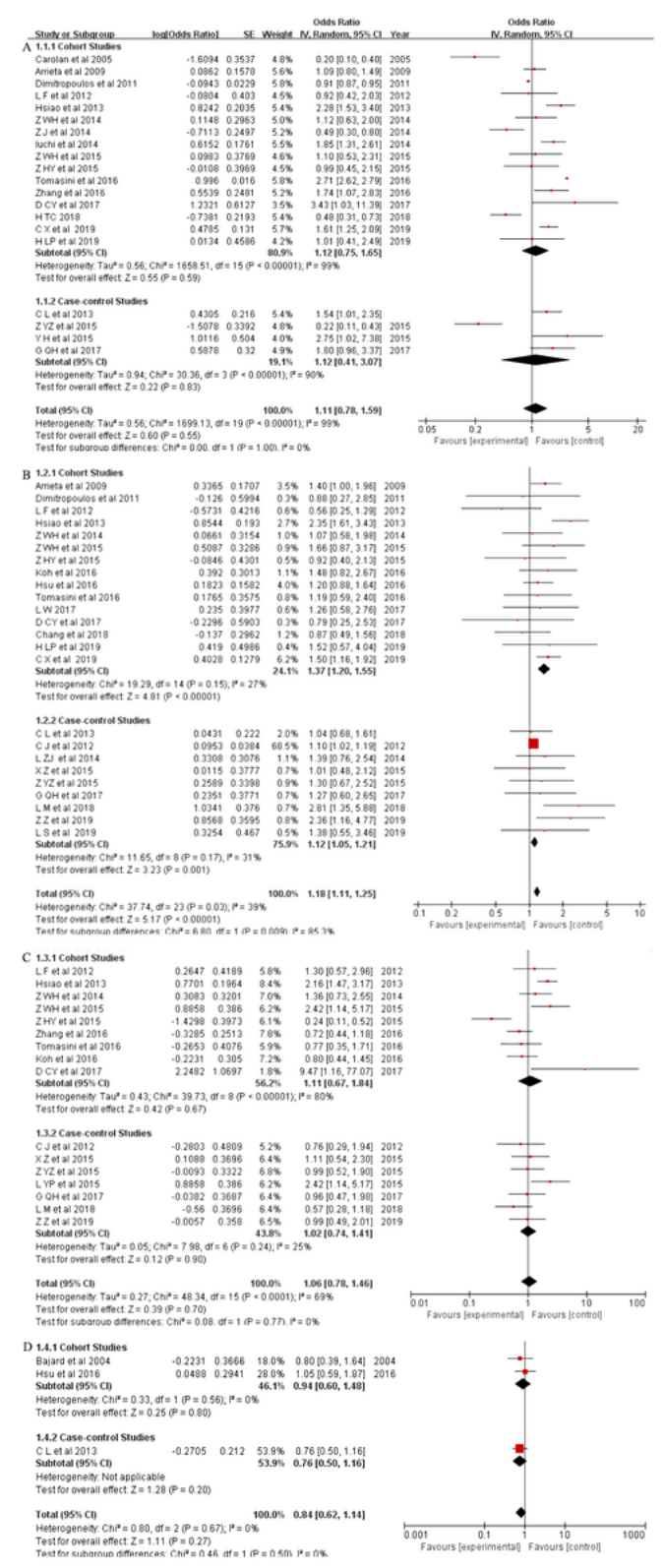

Figure 2

Meta-analysis of clinical characteristics. (A) age younger than 60 years old, (B) gender is female, (C) a smoking history, (D) a treatment history. 


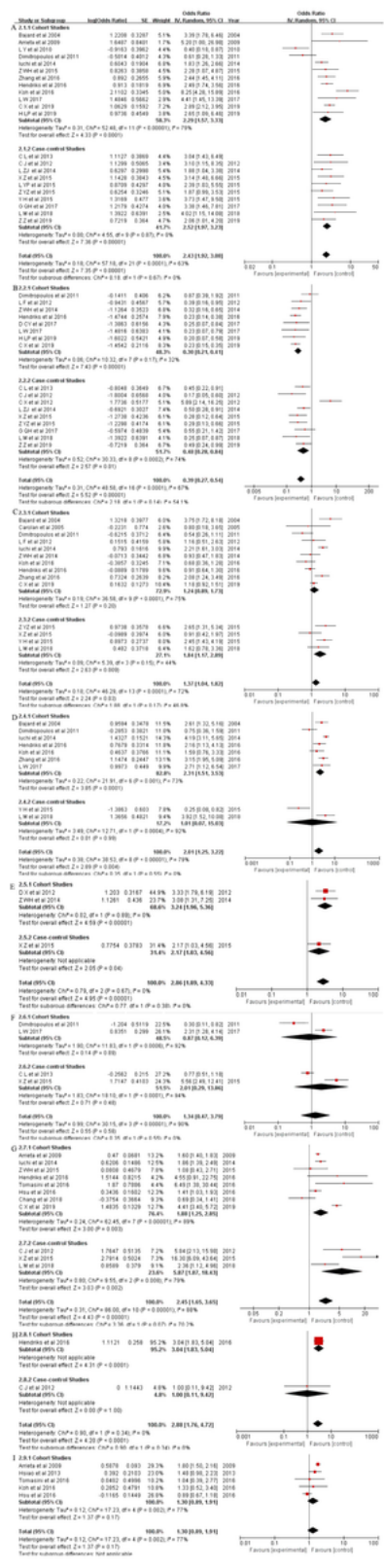

Figure 3

Meta-analysis of tumor-related indexes. (A) adenocarcinoma, (B) squamous cell carcinoma, (C) advanced tumor stage, (D) advanced node stage, $(E)$ the number of lymphatic metastasis more than 6, (F) distant metastasis, (G) EGFR gene mutuation, (H) KRAS gene mutation, (I)ECOG scale more than 2. Abbreviations: EGFR, epidermal growth factor receptor. 


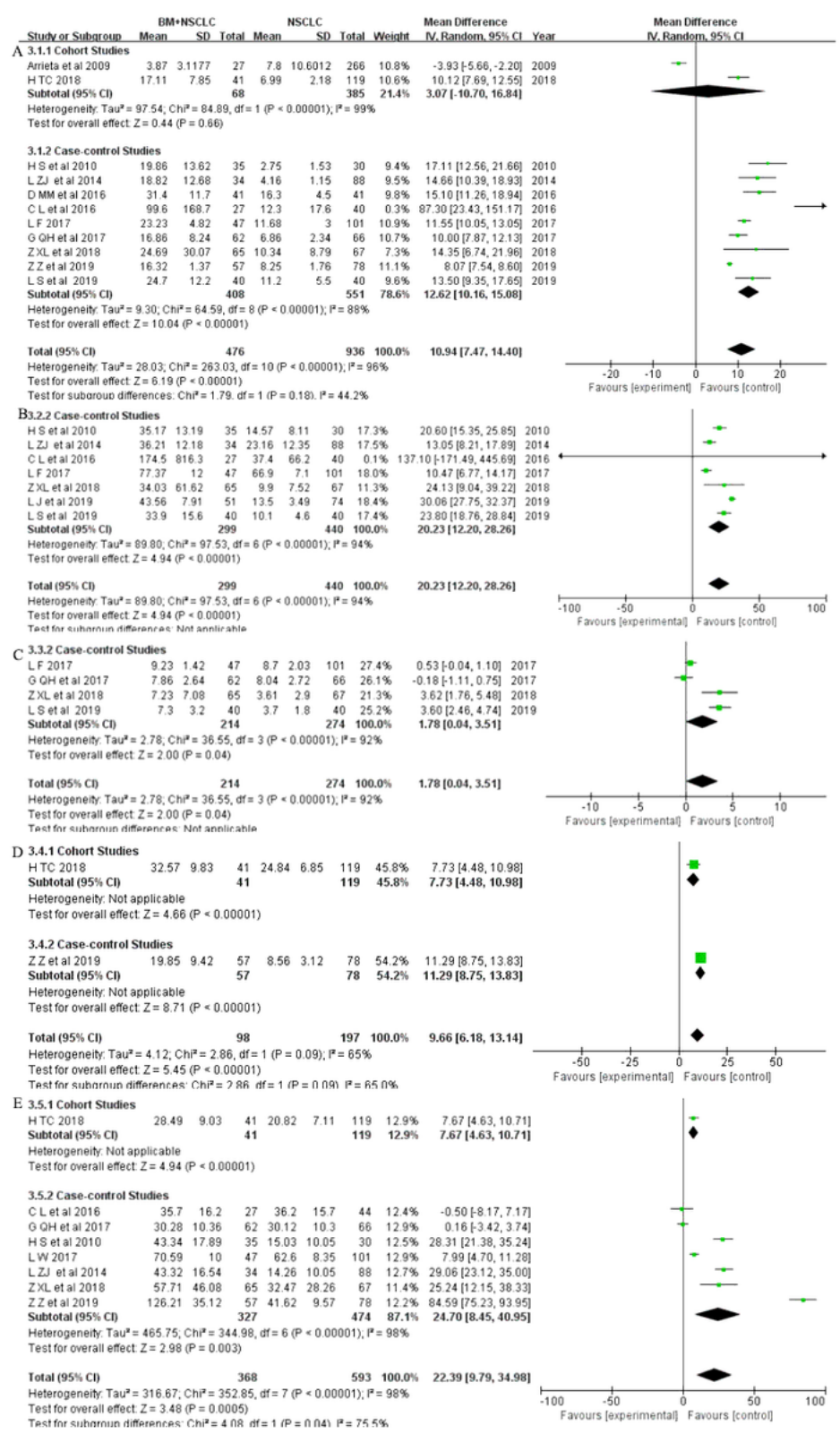

\section{Figure 4}

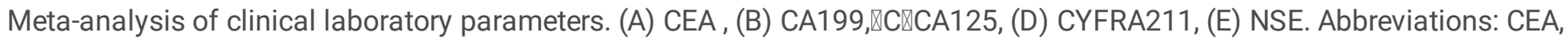
carcinoembryonic antigen; CA199, carbohydrate antigen 199; CA125, carbohydrate antigen 125; CYFRA21-1, cytokeratin-19 fragment; NSE, neuron-specific enolase. 


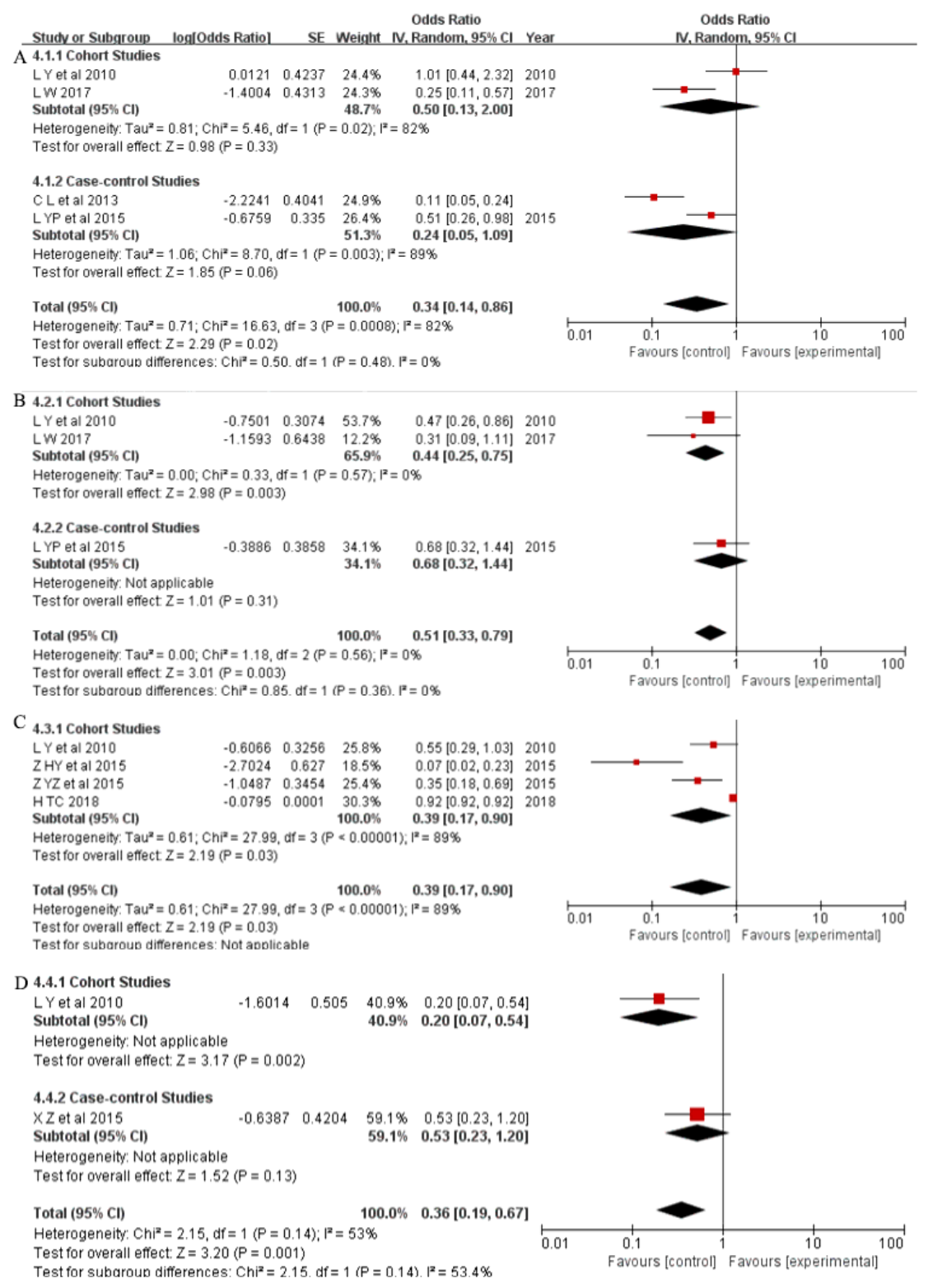

\section{Figure 5}

Meta-analysis of survival rates. (A) 1-year survival rate; (B) 2-year survival rate; (C) 5-year survival rate. 


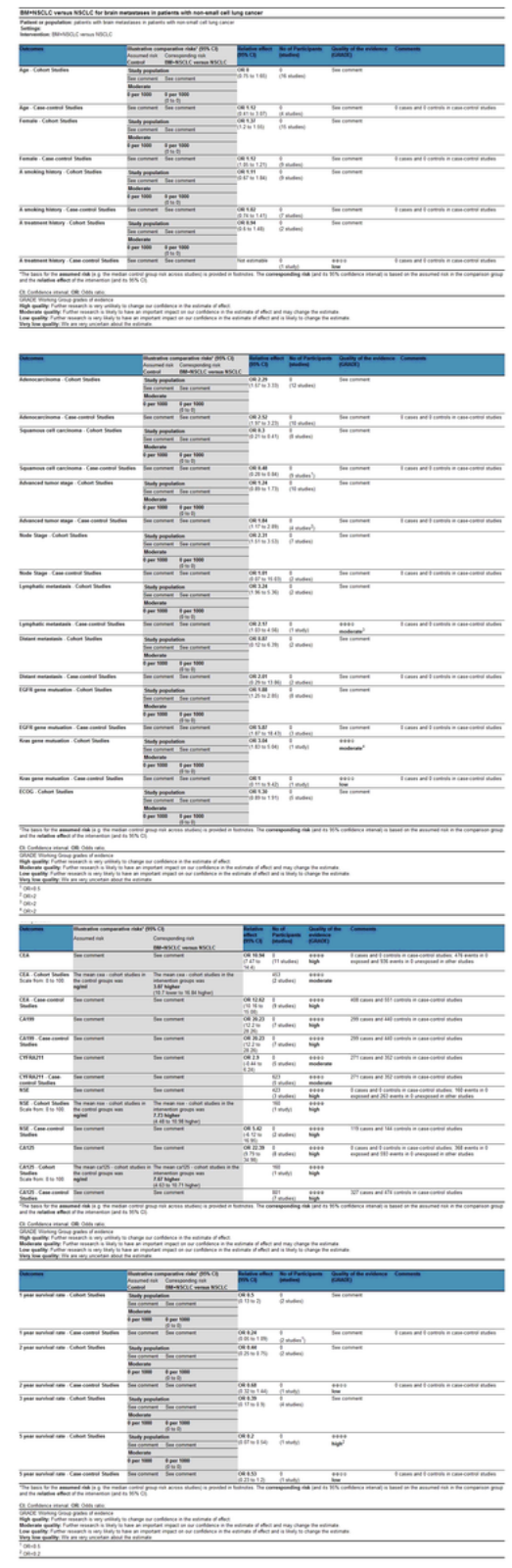

Figure 6

GRADE evidence profile 

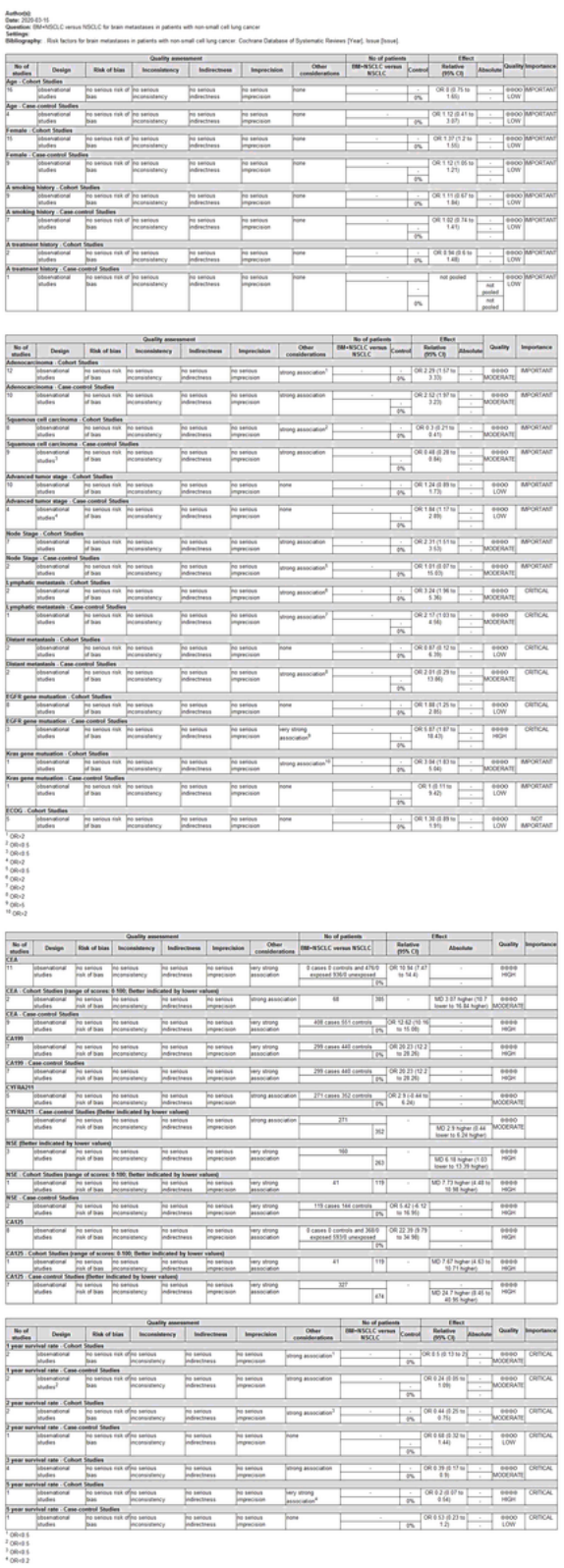

\section{Figure 7}

Summary of Findings table

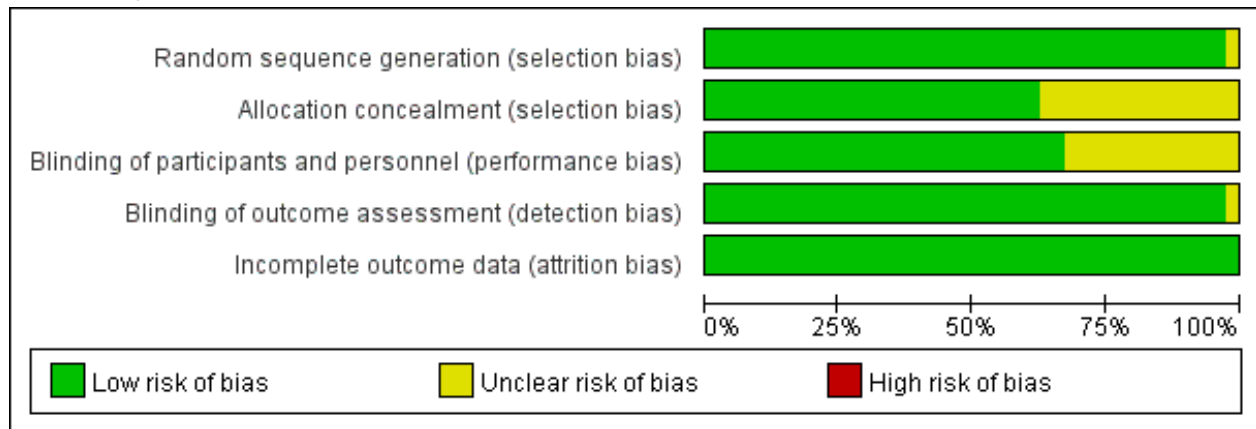

Figure 8

Risk of bias graph 


\begin{tabular}{|c|c|c|c|c|c|c|c|c|c|c|c|c|c|c|c|c|c|c|c|c|c|c|c|c|c|c|c|c|c|c|c|c|c|c|c|c|c|c|c|c|c|c|c|}
\hline & 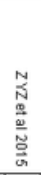 & & & & & & & & & & & & 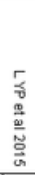 & 气̊ & & & & & & & & & 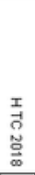 & & 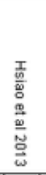 & & & 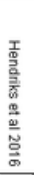 & & & 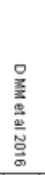 & & & & 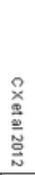 & & $\begin{array}{l}\frac{m}{\underline{m}} \\
\underline{\underline{w}}\end{array}$ & & & & 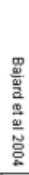 & & \\
\hline$\odot$ & $\odot$ & $\odot$ & $\odot$ & $\odot$ & $\odot$ & $\odot$ & ๑ & $\odot$ & $\odot$ & $\odot$ & $\odot$ & $\odot$ & $\odot$ & $\odot$ & $\bullet$ & $\odot$ & $\odot$ & • & ๑) & ๑ & $\odot$ & ๑ & $\odot$ & $\odot$ & $\odot$ & ๑ & • & • & $\odot$ & $\odot$ & $\odot$ & $\odot$ & ๑ & $\odot$ & $\odot$ & $\odot$ & $\odot$ & $\odot$ & $\oplus$ & $\odot$ & $\odot$ & • & Random sequence generation (selection bias) \\
\hline$\omega$ & $\odot$ & $\odot$ & ๑ & $\sim$ & $\sim$ & $\odot$ & ๑ & ๑ & ๑ & $\odot$ & $\mathcal{\odot}$ & $\omega$ & $\odot$ & ๑ & ๑ & $\odot$ & $\odot$ & ๑) & ๑ & ๑ & ๑ & ๑ & ๑ & $\omega$ & $\odot$ & $\omega$ & $\odot$ & ๑ & ๑ & $\oplus$ & $\omega$ & ๑ & $\approx$ & ๑ & $\omega$ & $\omega$ & $\omega$ & $\odot$ & $\sim$ & 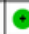 & $\odot$ & ๑ & Allocation concealment (selection bias) \\
\hline - & $\odot$ & $\odot$ & $\odot$ & $\odot$ & $\odot$ & $\odot$ & ๑ & $\odot$ & $\odot$ & $\odot$ & $\odot$ & $\odot$ & $\odot$ & • & $\odot$ & ๑๑ & $\odot$ & ๑) & ๑ & $\odot$ & $\bullet$ & $\odot$ & $\odot$ & $\odot$ & $\odot$ & $\odot$ & • & • & $\odot$ & $\odot$ & $\odot$ & • & $\sim$ & ๑ & $\odot$ & $\odot$ & $\odot$ & $\odot$ & 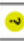 & + & $\odot$ & $\omega$ & Bilnding of participants and personnel (pertormance bias) \\
\hline$\odot$ & $\odot$ & $\odot$ & • & ๑ & $\odot$ & $\odot$ & ๑ & $\odot$ & $\odot$ & $\odot$ & $\oplus$ & $\odot$ & $\odot$ & • & $\odot$ & ๑ & $\odot$ & $\odot$ & ๑ & • & $\odot$ & $\oplus$ & $\odot$ & $\odot$ & $\odot$ & $\odot$ & $\odot$ & $\odot$ & $\odot$ & $\odot$ & $\odot$ & ๑ & ๑ & $\odot$ & $\odot$ & $\odot$ & $\odot$ & $\odot$ & $\odot$ & 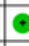 & $\odot$ & ๑ & Binding of outcome assessment (detection bias) \\
\hline$\odot$ & $\odot$ & $\odot$ & $\odot$ & $\odot$ & $\odot$ & $\odot$ & ๑ & $\odot$ & $\odot$ & $\odot$ & $\bullet$ & $\odot$ & $\odot$ & $\odot$ & • & ๑ & $\odot$ & $\odot$ & ๑ & ๑ & $\bullet$ & • & $\odot$ & $\odot$ & • & $\odot$ & $\odot$ & $\odot$ & $\odot$ & $\odot$ & $\odot$ & • & ๑ & $\odot$ & $\odot$ & $\odot$ & $\odot$ & $\odot$ & $\odot$ & $\mathbb{0}$ & $\odot$ & $\odot$ & Incomplete outcome data (atrrition bias) \\
\hline
\end{tabular}

\section{Figure 9}

Risk of bias summary

\section{Supplementary Files}

This is a list of supplementary files associated with this preprint. Click to download.

- S2PRISMAchecklist.pdf

- S2PRISMAchecklist.pdf

- Fig.S1.pdf

- Fig.S1.pdf 